Associate professor Jelena Ž. Maksimović

Faculty of Philosphy, University of Nis

Phd student Aleksandra S. Jovanović ${ }^{2}$

Faculty of Philosphy, University of Nis
Original scientific paper

UDC: 379.831

DOI: $10.17810 / 2015.101$

\title{
SOCIOMETRIC STATUS OF ADOLESCENTS AND SPORT ORIENTATION: CASE STUDY
}

\begin{abstract}
Summary: Being physically active and doing sports in adolescence is significant during regular education, as well as in free time. It contributes the most to socialization, development of cooperation and a healthy competitive spirit. The aim of this research is to determine the existence of a mutual connection between social status of adolescents and sport orientation with a case study of one class that achieves great results in school. The results of the research have shown that orientation towards sports and physical activities affects social status of students, that is, students chosen for joint activities in sports are also students who have positive sport preferences. Social status of students is conditioned by physical activity in P.E. lessons, as well as preferences towards group sports $(p<0.01)$, whereas the importance of the idea of sport and the degree of doing sport activities in free time, is not linked to social status in class in terms of sport activities. With this, we conclude that school is an important factor in developing social competences of students.
\end{abstract}

Key words: case study, physical activity, sociometric status, sport at school, sport preferences.

\section{Introduction}

The significance of physical activity for all spheres of development has been undoubtedly proved in the past decades. Physical education is an integral part of curriculum in the period of education and within a compulsory subject it is implemented three times a week. With the introducion of educational standards the achievements which learners should achieve in the subject Physical education regarding skills knowledge and evaluation of physical activity were defined. Aside from practical skills, a student acquires specific knowledge about physical activity and its wellness, but also builds attitudes that should be positive and contribute to physical activity in adulthood. A student should be aware of the fact that physical activity and sport should lead to interpersonal cooperation and team work, but also to the building of the character and develop personality (Repic-Cujić et al., 2010). Physical activity at an early school age significantly contributes to the development and popularization of sports and a helathy lifestyle. When adequately programed, that is, categorized, it can positively affect the development of morphological characteristics of students (Zrnzevic \& Zrnzevic, 2017). More

\footnotetext{
1 jelena.maksimovic@filfak.ni.ac.rs

ªleksandra.s.jovanovic.88@gmail.com
} 
positive attitudes on the significance of sports and physical activity are pronounced in elementary students, that is, students are more active than the students in high schools. High school students show more mature attitudes, but they are less active in school sports. Students show hesitation in terms of their belief regarding the realtionship of popularity and participation in sports (Savic et al., 2015).

Doing sports or any other kind of physical activity, recreationally or professionally, has shown benefits in many areas of life. It makes people happier, it stimulates brain activity, it increases self confidence, reduces stress and anxiety, friendships are formed with mutual activities. Much research has shown that physical activity has an influence on preventing the occurrence of many illnesses such as obesity, depression, mental health, osteoporosis, cancer, cardiovascular diseases, diabetes, and asthma at a primary as well as at a secondary level when the illness occurs (Blair, Kohl \& Gordon, 1992; Elmagd, 2016; Warburton, Nicol \& Bredin, 2006; Logstrup et al., 2001; Strong et al., 2005).

A world study of life values was carried out in the period of 2010 to 2014 and it encompassed around 100 countries. The results indicated that health, as one of the universal values of society, in the population up to 29 years of age, is estimated as very good in countries such as Zimbabwe, Jordan, Qatar, as bad in New Zeland, Egypt, Japan, Azerbaian, Algeria and Haiti. In a great number of countries, individuals do not do sports actively. The most active are people in Netherlands and New Zeland (Inglehart et al., 2014). Data from 2006 showed that young people in Serbia, aged up to 29 years, estimated their health as very good, but also as good and bad. Only $11.6 \%$ out of 311 respondents were active members of some sport organization and those were usually male respondents (Inglehart et al., 2014a).

Adolescence is a period of growing up, prone to abrupt changes and intense reactions, intensive physical development, development of emotional intelligence, skills of cooperation, building of identity. Social identity is built in a group of peers, that is, a certain status is taken, friendships are made, emotional support is seeked, adolescents learn about their capabilities and build their personality. The ability of children to adjust in the period of adolescence is connected to the ability to adjust in adulthood (Brkovic, 2011). It is through physical activity that some deviant forms of behaviour can be replaced. Aside from school obligations, students have a great part of their free time that they should spend precisely through physical activity. Physical activity can be individual and group, and thus contributes to social development of an individual since it requires interaction, cooperation, communication, development of a healthy competative spirit. In this paper we put stress precisely on social dimension, that is, the influence of sport preference on social status in class and vice versa. Moreno (Moreno, 1978) understands social status as an individual's position in a group that is determined by accepting or rejecting by other members of the group. Sociometry is the most adequate technique to determine this status. However, determining a social status of a group that is constant and in which all achieve great results in school is interesting, and it represents a case study that according to Yin (2009) should give us an answer to the question how and why a certain social phenomenon functions. As a case study, it has its advantages and faults. The advantages are that it essentially learns about a specific case, whereas the faults are reflected in generalizations, where on the basis on one case conclusions are made, which should not be true for all other cases. A foundation for creating hypothesis of research is a starting one (Sevkusic, 2008). 
Factors that affect popularity in a group can be gender, social behaviour, social skills, physical ability and attraction, academic achievement. The relationship between social status, that is, a position of an individual in class and his academic achievement is a subject of many researchers. It is attempted at explaining whether academic achievement can balance with popularity. A positive relation was shown in sociometric status, that is, accepting in a group. Physical ability and attraction of male students can lead to poor relationships (LaFontana \& Cillessen, 2002). Good social status and good grades in school are characteristic for females. A positive relation was shown in male students in classes where motivation for learning is at a high level, whereas in classes where low motivation is dominant, negative relation was shown (Titkova, Ivaniushina \& Alexandrov, 2013). Some research has shown that school success affects acceptance but not a social status in class, as well as that there are gender differences from the perspective of relation of school success and social status, which has opened the door for new research (Gadzic \& Milojevic, 2009).

\section{Methodology of research}

\section{The objective of research}

The objective of the research is to use case study of students of one class with great school achievement to determine sociometric status from the perspective of sport activity. Specific goals are to determine if physical activity in P.E. lessons and in free time, the importance of physical activity and sport preferences affect social status in students who learn in one constant group, that is, accepting or rejecting.

\section{Hypotheses}

The general hypothesis that we started from is that social status, that is, accepting or rejecting students in class, is conditioned by sport preferences.

$\mathrm{H} 1$ - Social status of students in class is conditioned by physical activity in P.E. lessons.

$\mathrm{H} 2$ - Social status of students in class is conditioned by physical activity in free time.

$\mathrm{H3}$ - Social status of students in class is conditioned by the attitudes on the importance of physical activity.

H4- Social status of students in class is conditioned by preferences towards physical activities in groups or pairs.

\section{Sample}

The sample of the research is intentional. Twenty-seven student of one class in the third grade of a secondary vocational school from the territory of the city of Nis participated in the study. They achieved the best results in the entire school in year 2017/2018. Nineteen students are female and eight students are male. The specificity of this research is refelected in the fact that all the students in the class achieved the best result in school two years consecutively. The average grade of the class is 4.65 , that is, four students achieved very good general success. Twelve students train a sport and two students are involved in sport sections at school. 


\section{Variables}

Independent variables of this research are students' orientation towards sports, that is, physical activity in free time and at school, physical activity in pairs or group, the importance/significance of physical activity. Dependent variable of the research is sociometric status of students in class from the perspective of sport activity.

\section{Methods, techniques and instruments of the research}

In this research we used descriptive method, case study and sociometry, and from the tecniques, we used a sociometric questionnaire. Sociometric questionnaire, Sociometric Status and Sport (SSIS), was made for the needs of this research, on the basis of 'The questionnaire of activities and choises of partners', by the authors Potkonjak and Trnavac $(1998,118)$. In the introductory part of the questionnaire, students answered five questions on sport preferences. They also declared according to which sports they feel indifferent, which sport they like and which sport they do not like. They were presented with 17 sports. A second part of the questionnaire refers to a sociometric test where students should select with whom they want to spend the most, want less or do not want to spend time in sport activities for which they declared whether they love them, do not love them or they feel indifferent.

\section{Organization and the course of the research}

The research was realized in 2018 in the school, after the signed consents of parents to allow their children to participate in the research. Students were given the questionnaire during the class with their class teacher, they were instructed how to fill in, and they were allotted enough time to think and fill in.

\section{Statistical processing of data}

A sociometric matrix was designed according to students' selections over with what students they want the most, want less or do not want to participate in sport activities. Students could name more than one student, that is, select more than one student with whom they would want to do sports. Students were divided into groups, categories according to how active they are in P.E. lessons, in their free time, their attitudes on the importance of doing sports, preferences of group or individual sports.

For each category of students the number of selections for I want the most, the number of I want less and I do not want were added up. By summing all selections by the others, for each student, a number of selections is obtained, $\mathrm{N}$, that represents the sum of all students' selections altogether. Given the amount of sample, data were processed by calculating an $\chi^{2}$ Test with which the intensity of relationship among variables and contigency coefficient (C) with which the intensity of concurrence among the observed variables is determined. This concurrence is verified by the calculation of maximum value of contigency coefficient (Cmax). 
Picture 1: Sociometric matrix

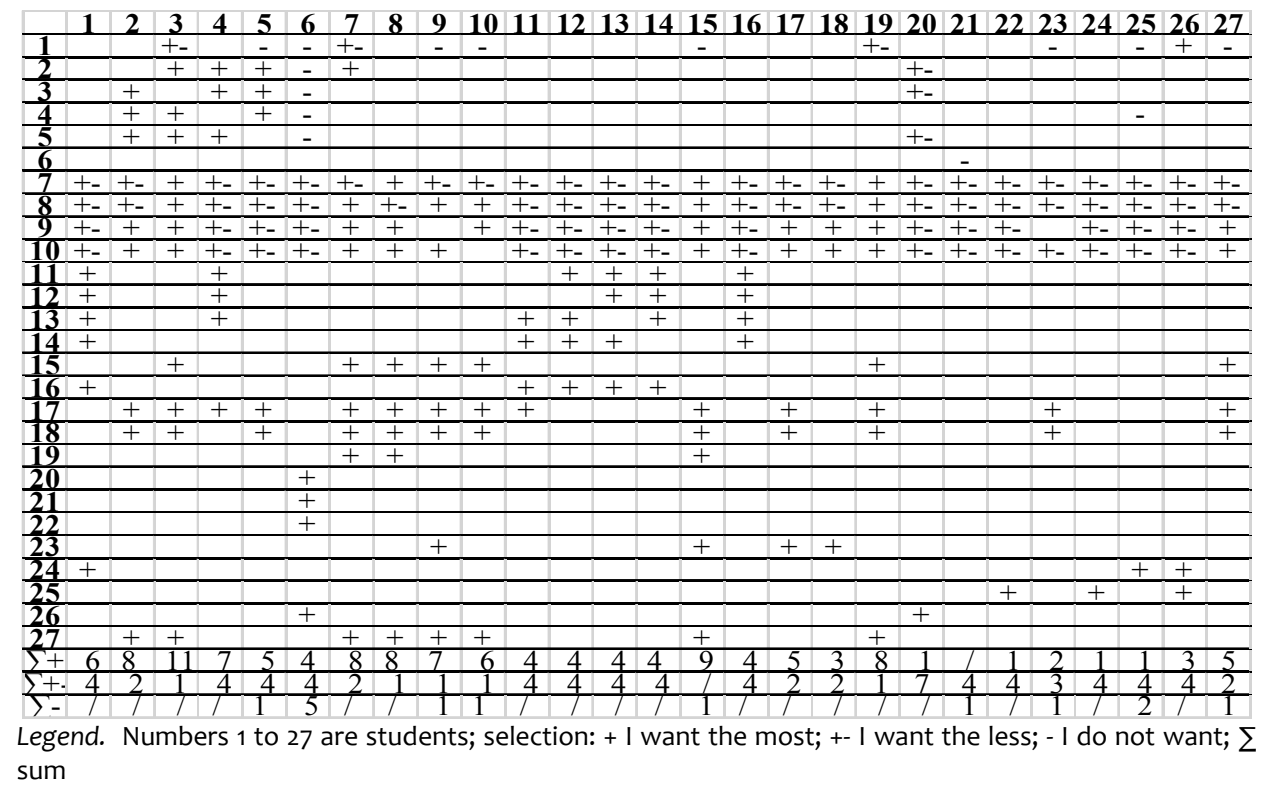

The design of sociometric matrix meant a tabular view of all students, where the numbers of selections by other students were written next to students' names, for the categories I want the most, I want less and I do not want to do sports (Picture 1).

Picture 2: Classifying students into categories

\begin{tabular}{|c|c|c|c|c|c|c|c|c|c|c|c|}
\hline & Always & $\begin{array}{c}\text { Almost } \\
\text { always }\end{array}$ & Rarely & $\begin{array}{c}\text { Every } \\
\text { day }\end{array}$ & $\begin{array}{c}\text { Several } \\
\text { times a } \\
\text { week }\end{array}$ & $\begin{array}{c}\text { Several } \\
\text { times a } \\
\text { month }\end{array}$ & $\begin{array}{c}\text { Very } \\
\text { important }\end{array}$ & Important & $\begin{array}{c}\text { Less } \\
\text { important }\end{array}$ & Couple & Group \\
\hline 1 & * & & & * & & & $*$ & & & $*$ & \\
\hline$\frac{2}{2}$ & $*$ & & & & & * & & * & & & * \\
\hline 3 & & * & & * & & & & * & & & * \\
\hline 4 & & * & & & & * & & & * & 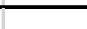 & * \\
\hline 5 & & * & & & * & & & * & & & * \\
\hline 6 & & & * & & & * & & * & & & \\
\hline 7 & & * & & & $*$ & & $*$ & & & & * \\
\hline 8 & & * & & & $*$ & & $*$ & & & & * \\
\hline 9 & $*$ & & & & & * & $*$ & & & & * \\
\hline 10 & & & & & * & & $*$ & & & & * \\
\hline 11 & & * & & * & & & $*$ & & & & * \\
\hline 12 & & * & & & * & & $*$ & & & & * \\
\hline 13 & & * & & & * & & & & * & 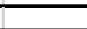 & * \\
\hline 14 & & & & & * & & & * & & & * \\
\hline 15 & & & & & * & & $*$ & & & & * \\
\hline 16 & & * & & & & * & & * & & & * \\
\hline 17 & & * & & & & * & & * & & & * \\
\hline 18 & & & * & & & * & & & $*$ & & * \\
\hline 19 & $*$ & & & & * & & & * & & & * \\
\hline 20 & $*$ & & & & * & & & * & & * & \\
\hline 21 & & * & & & & * & & * & & $*$ & \\
\hline 22 & & * & & & & * & $*$ & & & $*$ & \\
\hline 23 & & & & & * & & & * & & & * \\
\hline 24 & & * & & & * & & & * & & & * \\
\hline 25 & $*$ & & & * & & & $*$ & & & & * \\
\hline 26 & * & & & * & & & $*$ & & & & * \\
\hline 27 & $*$ & & & & $*$ & & $*$ & & & & * \\
\hline
\end{tabular}


In order to perceive certain categories of selections, a special matrix was designed where students were categorized in groups, according to certain categories, that is, their answers such as always, almost always, rarely, every day, several times a week, several times a month, very important, important, less important, pair, group (Picture 2).

\section{Research results}

The class consists of students who train athletics, volleyball, footsall, football, folklore dance, basketball, kick boxing, tennis, those who go to the gym. The greatest number of students choose more than one students for sport activities, which indicates that sociometric status of the class is favourable, that is, that students interact and cooperate when it comes to sports. Two students responded that they are rarely active in P.E. lessons, 13 students are almost always active and 12 students are always active. Five students are active every day, 13 students several times a week and 9 students several times a month. Fifteen students responded that it is very important to be physically active, 9 students responded that it is important to be active and 3 students that it is less important.

The results have shown that there is a statistically significant difference, since the obtained $\chi^{2}$ test is significant at level 0.00 . The degree of students' physical activity in P.E. classes conditions the number of other students' selecting them. The overall number of all selections is 225 , whereas there were 63 positive selections in groups of almost always active students in P.E. lessons. More physically active students are more selected for sports than those who are less physically active (Table 1 ).

Table 1: Social status of students and physical activity in P.E. classes

\begin{tabular}{llll|l}
\hline & Always & Almost always & Rarely & $\sum \mathrm{N}$ \\
\hline I want the most & 60 & 63 & 7 & 130 \\
I want less & 33 & 42 & 6 & 81 \\
I do not want anyway & 7 & 2 & 5 & 14 \\
\hline$\sum \mathrm{N}$ & 100 & 107 & 18 & 225 \\
\hline \multirow{2}{*}{$\chi^{2}$} & $\mathrm{P}$ & $\mathrm{C} / \mathrm{C}_{\max }$ & $\mathrm{df}$ \\
\cline { 2 - 6 } & 18.62 & 0.00 & $0.76 / 0.82$ & 4 \\
\hline
\end{tabular}

Legend. $\mathrm{N}$ - number of choices

It was shown that the incidence of physical activity in free time does not significantly affect social status in the class in terms of sports ( $p>0.05$; Table 2$)$.

Table 2: Social status of students and physical activity in free time

\begin{tabular}{llllll|l}
\hline & Every day & $\begin{array}{l}\text { Several times a } \\
\text { week }\end{array}$ & $\begin{array}{l}\text { Several times a } \\
\text { month }\end{array}$ & $\sum \mathrm{N}$ \\
\hline I want the most & 27 & 66 & 39 & 27 & 132 \\
I want less & 17 & 37 & 7 & 81 \\
I do not want anyway & 2 & 5 & 73 & 14 \\
\hline$\sum \mathrm{N}$ & 46 & 108 & $\mathrm{C} / \mathrm{C}_{\max }$ & $\mathrm{df}$ \\
\hline & $\mathrm{X}$ & $\mathrm{P}$ & $0.11 / 0.82$ & 4 \\
\hline
\end{tabular}

Legend. $\mathrm{N}$ - number of choices 
The overall number of all selections is 227 , whereas there were 66 positive selections in groups of students who do sports several times a week. More physically active students in their free time are not necessarily the most selected ones for joint sport activities (Table 2).

It was shown that there is not a statistically significant difference between social status of students in terms of sports and the understanding of the importance of sports. The concurrence among the observed phenomena is weak. Regardless of the individual degree of understanding the importance of sports, students mutually select one another for sport activities ( $p>0.05$; Table 3). The overall number of all selections is 222 , whereas there were 61 positive selections in groups of students who find physical activity very important (Table 3 ).

Table 3: Social status of students and importance of sports

\begin{tabular}{llll|l}
\hline & Very important & Important & Less important & $\sum \mathrm{N}$ \\
\hline I want the most & 61 & 53 & 14 & 128 \\
I want less & 31 & 40 & 10 & 81 \\
I do not want anyway & 6 & 7 & $/$ & 13 \\
\hline$\sum \mathrm{N}$ & 98 & 100 & 24 & 222 \\
\cline { 2 - 6 } & $\mathrm{X}$ & $\mathrm{P}$ & $\mathrm{C} / \mathrm{C}_{\max }$ & $\mathrm{df}$ \\
\cline { 2 - 5 } & 3.37 & $>0.05$ & $0.01 / 0.82$ & 4 \\
\hline
\end{tabular}

Legend. $\mathrm{N}$ - number of choices

It can be concluded that there is a statistically signficant difference between social status of students and their preferences to do sports in groups or pairs, since the obtained $\chi^{2}$ test is significant at level 0.00 (Table 4).

Table 4: Social status of students and physical activity in groups or pairs

\begin{tabular}{lll|l}
\hline & Couple & Group & $\sum \mathrm{N}$ \\
\hline I want the most & 8 & 125 & 133 \\
I want less & 19 & 62 & 81 \\
I do not want anyway & 1 & 13 & 14 \\
\hline$\sum \mathrm{N}$ & 28 & 200 & 228 \\
\hline$\chi^{2}$ & $\mathrm{P}$ & $\mathrm{C} / \mathrm{C}_{\max }$ & $\mathrm{df}$ \\
\hline 25.56 & 0.00 & $0.10 / 0.82$ & 2 \\
\hline
\end{tabular}

Legend. $\mathrm{N}$ - number of choices

The biggest number of students opt for group sports opposed to pair sports, that is, 4 students opt for pair sports, one student selects only one student for the category I do not want to do sports. Those four students were selected by other students 27 times. The remaining 22 students opted for a large number of students with whom they want to do sports, they select more than one, that is, they are selected 228 times by others, and 125 times positively, which can indicate that students prefer sports for more people. Students who have a larger number of selections by others, or better social status in class, strive for group physical activities. This shows that students mutually socialize and cooperate, and that they love to do sports together (Table 4). 


\section{Discussion}

The significance of sociometric study of physical activities within sport groups is reflected in viewing the interaction of group members and their positive influence on achieving success. It is understood that group members will turn to each other and that sociometry will show there is one person in the group that stands out, the person that is also the captain, group leader, which was shown by the research (Sabin, Mihai \& Marcel, 2014; Sindik \& Mihaljevic, 2011). Sport groups are characterized by communication, cooperation, interaction and counselling about decision making. Students who achieve good results in school are being elected for formal leaders, and they affect the process of decision making of other group members (Sabin \& Marcel, 2014). Without positive social interactions, good results cannot be expected. In such groups each has its role that leads to a common goal, achieving success. When it comes to a school group that achieves great results in all subjects and sports, it is interesting to find if some individuals stand out according to social status in comparison to sport preferences. Our research has shown that one student has the biggest number of selections by others, that is, 11 selections, so we cannot conclude that he is the formal leader in sport activities of the class.

Aside from sociometry, observation as a method of research completes the objectivity of results about the interactions of peers within a sport group. More popular active adolescents are more selected, that is, accepted by their peers, and they are the most accepted by their coach. Those who are rejected by their peers are evaluated as less competent in sports, which proves that sport competence affects social status. However, it was shown that more competent adolescents communicate more with their coaches than with their peers, which also affects the quality of friendship with others (Vierimaa \& Cote, 2016). Our research has indicated that students have good social status in class in terms of sport activities.

Much research has shown the positive correlation of physical activity and academic success, which is explained by the influence of physical activity on concentration, memory and the development of intelligence (Strong et al., 2005). Our research confirms this hypothesis, since it has been shown that students are mostly positively sports-oriented.

School should contribute to popularization of sports aside from compulsory classes (Logstrup et al., 2001). The organization of free sport activities, participation of students in sections and interclass competitions contribute to the development of sport spirit and understanding the importance of doing sports. The students of examined class are almost always and always active in P.E. classes, but they are not all involved in sport sessions, on which school should work.

According to Bailey (2006), basic advantages of doing sports in school are physical, emotional, social and cognitive development, as well as a healthy lifestyle. It should stress encouraging the development of social skills, which are acquired with the relationship among peers, as well as a relationship with teachers. Emotional intelligence, that is, the ability to control emotions affects academic success, as well as achievement in sports (Lozovina, Bonacin \& Lozovina, 2012). Emotional stability is influenced by many factors, but most certainly acceptance by group members is an important factor that will contribute to success in school, as well as sports. Smith (Smith, 2003) points that peers may influence one another, that is, the level and quality of physical activity with their incentive. A favourable social status of students of our class proves that sports is important for the development of social and emotional skills. Our results have shown that activity in P.E. classes and favourable status are correlated. 
Motivation of adolescents to do sports affects their physical activity. It is significant that teachers give students themselves freedom to choose activities that they will do in regular instruction, and thus contribute to the development of autonomy in students (Ntoumanis, 2001). Students who have more confidence and better self-opinion are more motivated to do sports (Jekauc et al., 2017; Ntoumanis, 2001).

Research shows that boys and children of younger age are more active than girls and adolescents (Van Hecke et al., 2016). Male students at a primary and secondary level are more engaged in sport activities, which is certainly necessary to change by encouraging female population to be active. Students are more active in primary school, and they do sports the most in P.E. lessons. In free time, they prefer collective sports such as basketball and volleyball in boys, and in girls dance, running, walking, which shows different sport preferences of boys and girls (Radisavljevic-Janic, Milanovic \& Lazarevic, 2012). Our sample is not balanced when it comes to gender, but it was shown that students love the most fitness/gym, volleyball, cycling, hiking, table tennis, tennis, football, and they opt least for riding, archery, badminton, running and martial arts sports.

Research of young people in Serbia has shown that the greatest number of respondents aged up to 19 years of age do not do sports. Male respondents do sports more. Adolescents take 120 minutes at most to do physical activities, but only a quarter of respondents do so. Young people are aware that they do not do sports enough, which is a good marker for them to start being active. However, they grade their health as very good and good (Ministarstvo omladine i sporta Republike Srbije, 2016). Our results have shown that students are aware of the importance of sports and a large number of them choose to do sports a couple times a week.

There are indicators that school achievement of adolescents is not conditioned by doing sports, but that students who actively do sports achieve better results in school, which opens the door for implementing new research and discovering factors that lead to better results of athlete students (Gadzic \& Milojevic, 2009). It has also been shown that doing sports does not affect social relationships and that in some cases sociometrical status is not conditioned by doing sports (Edim \& Odok, 2015; Gadzic \& Vuckovic, 2009). Our results have shown that activity in P.E. lessons and favourable social status correlate.

We have confirmed general hypothesis, that is, sociometric status is conditioned by sport preferences, that is, the degree of activity in P.E. lessons, as well as preferences towards group sports. The degree of understanding of sports, as well as doing sport activities in free time, do not affect social status of students.

\section{Conclusion}

Even though there are tendencies that sports represents only a kind of profit, it is necessary to stress its moral function, as well as aesthetic (Randelović \& Savic, 2016). Cooperation and togetherness, as well as a relationship towards beauty should be starting points in a series of advantages of doing sports.

Many European countries are not satisfied with the position of school sports in curriculum as well as in free time activities. It is necessary to convert desires into reality and deal more with adequate ways of popularizing sports and putting it in the function of personality development (Hardman, 2008). 
On the basis of the obtained results of this research, we can conclude that the class in which students achieve great results, is a class that is physically active, with good sociometric status, where there is cooperation and aspiration towards mutual activities in sports. Aside from school obligations, students do sports in their free time, and most importantly, they understand the importance of sports. The link of sociometric status of students and their activities in P.E. lessons exists, but it has not been shown in the cases of understanding the importance of sports and doing sports in free time. This shows that P.E. lessons are important for the development of cooperation and communion.

\section{References}

Bailey, R. (2006). Physical Education and Sport in Schools: A Review of Benefits and Outcomes, Journal of School health, 76 (8), 397-401.

Blair, S. N., Kohl, H. W. \& Gordon, N. F. (1992). How much Physical Activity is Good for Health?, Annu. Rev. Publ. Health, 13, 99-126.

Brkovic, A. (2011). Razvojna psihologija. Cacak: Regionalni centar za profesionalni razvoj zaposlenih u obrazovanju.

Edim, M. E. \& Odok, E. (2015). A Sports Participation and Social Personality Variable of Students in Secondary Schools in Central Senatorial District of Cross River State, Nigeria, Journal of Education and Practice, 6 (15), 135-138.

Elmagd, M. A. (2016). Benefits, Need and Importance of Daily Exercise, International Journal of Physical Education, Sports and Health, 3 (5), 22-27.

Gadzic, A. \& Milojevic, A. (2009). Skolski uspeh i status adolescenata u razredu. Teme, 33 (4), 1379-1389.

Gadzic, A. \& Vuckovic, I. (2009). Participation in Sports and Sociometric Status of Adolescents, Biomedical Human Kinetics, 1, 83-85. DOI: 10.2478/v10101-009-0021-y

Gadzic, A. (2009). Bavljenje sportom i uspeh u skoli ucenika adolescenta. Fizicka kultura, 63 (2), 243-254.

Hardman, K. (2008). The Situation of Physical Education in Schools. Human Movement, 9 (1), 518. DOI: 10.2478/v10038-008-0001-z

Inglehart, R., C. Haerpfer, A. Moreno, C. Welzel, K. Kizilova, J. Diez-Medrano, M. Lagos, P. Norris, E. Ponarin \& B. Puranen et al. (eds.) (2014). World Values Survey: Round Six Country-Pooled Datafile Version. Madrid: JD Systems Institute. Retrived July 19, 2018, from http://www.worldvaluessurvey.org/WVSDocumentationWV6.jsp

Inglehart, R., C. Haerpfer, A. Moreno, C. Welzel, K. Kizilova, J. Diez-Medrano, M. Lagos, P. Norris, E. Ponarin \& B. Puranen et al. (eds.) (2014a). World Values Survey: Round Five Country-Pooled Datafile Version. Madrid: JD Systems Institute. Retrived July 19, 2018, from http://www.worldvaluessurvey.org/WVSDocumentationWV5.jsp

Istrazivanje polozaja i potreba mladih u Republici Srbiji. (2016). Ministarstvo omladine i sporta Republike Srbije. Retrived July 19, 2018, from http://www.mos.gov.rs/public/ck/uploads/files/Dokumenta/Omladina/istrazivanja/istr azivanje\%202016/Istrazivanje\%2opolozaja\%20i\%2opotreba\%2omladih\%2oteren\%2odece mbar\%202016.pdf

Jekauc, D., Wagner M. O., Herrmann, C., Hegazy, K. \& Woll, A. (2017). Does Physical SelfConcept Mediate the Relationship between Motor Abilities and Physical Activity in Adolescents and Young Adults? PLOS ONE, 12 (1), e0168539. DOI: 10.1371/journal.pone.0168539 
LaFontana, K. M. \& Cillessen, A. H. N. (2002). “Children's Perceptions of Popular and Unpopular Peers: A Multimethod Assessment”. Developmental Psychology, 38 (5), 635-647. DOI:10.1037//0012-1649.38.5.635

Logstrup, S. (Ed.) (2001). Children and Young People - the Importance of Physical Activity. Brussels: European Heart Network, European Heart Health Initiative.

Lozovina, M., Bonacin, D. \& Lozovina, V. (2012). Emotional Intelligence and Determination of Sociometric Status in Sport. Sport Science, 5 (2), 66-74. DOI: 10.14687/jhs.v14i4.4839

Moreno, J. L. (1978). Who Shall Survive? Foundations of Sociometry, Group Psychotherapy and Sociodrama, $3^{\text {rd }}$ edition. Beacon N. Y., Beacon House Inc.

Ntoumanis, N. (2001). A Self-determination Approach to the Understanding of Motivation in Physical Education, British Journal of Educational Psychology, 71, 225-242.

Potkonjak, N. \& Trnavac, N. (1998). Instrumenti za rad skolskog pedagoga. Beograd: Pedagosko drustvo Srbije.

Radisavljevic-Janic, S., Milanovic, I., \& Lazarevic, D. (2012). Fizicka aktivnost adolescenata: uzrasne i polne razlike, Nastava i vaspitanje, 61 (1), 183-194.

Randelovic, M. \& Savic, Z. (2016). Uloga i znacaj skolskog sporta u procesu vaspitanja mladih, Teme, 40 (4), 1291-1305. DOI: 10.22190/TEME1604291R

Repic-Cujić, V., Visnjic, D., Radisavljevic, S., Gortnar, Z., Lepes, J., Zecevic, S. \& Krstic, K. (2010). Obrazovni standardi za kraj obaveznog obrazovanja za nastavni predmet Fizicko vaspitanje. Beograd: Ministarstvo prosvete Republike Srbije; Zavod za vrednovanje kvaliteta obrazovanja i vaspitanja.

Sabin, S. I. \& Marcel, P. (2014). Group Cohesion Important Factor in Sport Performance, European Scientific Journal, 10 (26), 163-174. DOI: 10.13140/RG.2.1.4593.4165

Sabin, S. I., Mihai, S. \& Marcel, P. (2014). The Importance and Utility of the Sociometric Survey Method in Physical Education Research, Procedia - Social and Behavioral Sciences, 117, 185-192. DOI: 10.1016/j.sbspro.2014.02.199

Savic, Z., Stojanovic, N., Randelovic, N. \& Stojiljkovic, N. (2015). The Differences in the Attitudes of Elementary and High School Children on the Importance and Development of School Sport, Facta Universitatis, Series: Physical Education and Sport, 13 (2), $229-240$.

Sevkusic, S. (2008). Kvalitativna studija slucaja u pedagoskim istrazivanjima: saznajne mogucnosti i ogranicenja, Zbornik Instituta za pedagoska istrazivanja, (2), 239-256. DOI:10.2298/ZIPI0802239S

Sindik, J. \& Mihaljevic, D. (2011). Socioekonomski status i mikrosocijalna struktura unutar zenskog rukometnog kluba, SportLogia, 7(2), 151-162. DOI: 10.5550/sgia.110702.se.151S

Smith, A. L. (2003). Peer relationships in physical activity contexts: a road less traveled in youth sport and exercise psychology research, Psychology of Sport and Exercise, 4, 25-39. DOI: 10.1016/S1469-0292(02)00015-8

Strong, W. B., Malina, R. M., Blimkie, C. J. R., Daniels, S. R., Dishman, R. K., Gutin, B., Hergenroeder, A. C., Must, A., Nixon, P. A., Pivarnik, J. M., Rowland, T., Trost, S. \& Trudeau, F. (2005). Evidence Based Physical Activity for School-age Youth, The Journal of Pediatrics, 146 (6), 732-737. DOI: 10.1016/j.jpeds.2005.01.055

Titkova, V., Ivaniushina, V. \& Alexandrov, D. (2013). Sociometric Popularity in School Context. Basic Research Program Working Papers, Series: Education. Saint Petersburg: National Research University Higher School of Economics (HSE). Retrived July 17, 2018, from https://www.hse.ru/data/2013/03/02/1293260250/10EDU2013.pdf

Van Hecke, L., Loyen, A., Verloigne, M., Ploeg, H. P., Lakerveld, J., Brug, J., De Bourdeaudhuij, I., Ekelund, U., Donnelly, A., Hendriksen, I. \& Deforche, B. (2016). Variation in 
population levels of physical activity in European children and adolescents according to cross-European studies: a systematic literature review within DEDIPAC. International Journal of Behavioral Nutrition and Physical Activity, 13:70. DOI 10.1186/s12966-016-0396-4

Vierimaa, M. \& Cote, J. (2016). An Exploration of Sociometric Status and Peer Relations in Youth Sport, Journal of Sport Behavior, 39 (1), 72-91.

Warburton, D., Nicol, C. W \& Bredin, S. (2006). Health benefits of physical activity: the evidence. CMAJ. 174 (6), 801-809. DOI: 10.1503/cmaj.051351

Yin, K. R. (2009). Case Study Research - Design and Methods, $4^{\text {th }}$ Edition, Applied Social Research Methods, Volume 5. SAGE Publications, Inc.

Zrnzevic, N. \& Zrnzevic, J. (2017). Programmed Physical Education Teaching and its Effects on Students' Motor Skills. Facta Universitatis, Series: Physical Education and Sport, 15 (3), 501-512. DOI: 10.22190/FUPES1703501Z

\section{Biographical notes:}

Dr Jelena Maksimović (1977) is Associate Professor at the Department of Pedagogy, Faculty of Philosophy at University of Niš for the subject: Methodology of pedagogy and Research in pedagogy. PhD thesis: The role of action research in improving educational practice, defended in 2011 at the Faculty of Philosophy, University of East Sarajevo, under the supervision of dr Veljko Banđur. Worked as a researcher at the science project Pedagogical pluralism as the basis for education policy (179036), in the category A1, funded by the Ministry of Science and Technological Development of Serbia for the period from January 2011. until December 2020. She also worked as a researcher at the international Tempus project: Leadership in education (EdLead) from 2013. to december 2017. Science Field: Methodology of pedagogical research, Statistics in pedagogy, Action Research, Data Processing in educational research.

Aleksandra S. Jovanovic (1988) is a Ph.D. student at the Faculty of Philosophy, Nis, Serbia. She studied pedagogy at the same faculty where she obtained her BA and MA degrees. She graduated in 2011. and defended her MA thesis entitled „Individualization in the Process of Descriptive Assessment of Students" in 2013. 